\title{
Do the Implementation of Green Practices Initiatives in Starbucks Increase the Number of Tourists to a City? (Study Case of Starbucks in Pontianak)
}

\section{Helma Malini}

Tanjungpura University , Pontianak, 78121 Indonesia

\section{Helma.malini@untan.ac.id}

\begin{abstract}
This study aims to examine the influence of Eco-friendly Practices, Green Brand Image and Green Initiatives on the number of tourists visiting Pontianak. The type of research used in this research is quantitative by using a survey method wherein survey research using a questionnaire that will be given to respondents according to predetermined criteria. The population of this research is the consumer who has visited, received offers and made purchase decisions at least two times for Starbucks products with the sample is 100 respondents. The technique used is non-probability sampling, which is a sampling technique that does not provide equal opportunities for each element or member of the population to be selected as samples and the purposive sampling method is a sampling technique with certain considerations. The data will be analyzed by using PASW Statistics 18 software application and the method used is multiple linear regression with the variables of Eco-Friendly Practices, Green Brand Image and Green Initiatives, and several tourists. The results of this research indicate that Eco-Friendly Practices, Green Brand Image and Green Initiatives have a significant effect number of tourists visiting Pontianak.
\end{abstract}

\section{ARTICLE HISTORY}

Submitted:21.06.2021

Revised:22.06.2021

Accepted:08.07.2021

Online first:10.07.2021

\section{KEYWORDS}

Eco-Friendly

Practices,

Green brand

image,

Green

Initiatives 


\section{Introduction}

In the global warming era, companies must have responsibility for the environment and apply the principle of environmentally friendly practices. According to (Jermsittiparsert et al., 2019), from the beginning of the 1980s, there have been ecological issues such as global warming because of the greenhouse effect, pollution, and climate changes that related to industrial manufacturing and it will affect human"s activities. Due to the increase of natural damage that happens in the world, a consumer has main concern regards to environmental protection and the great demand for green products (Xu \& Jeong, 2019). Then, managers of many companies see an opportunity for creating a strong brand name and increased their brand image (Tih \& Zainol, 2012). Because of that most of the companies have begun to create green initiatives and build a green brand image by applying eco-friendly practices that can protect the environment and solve ecological issues while satisfying consumerse preferences to make long term profits in businesses and long-term interest toward consumers.

Starbucks Corporation is an American multinational chain of coffeehouses and roastery reserves headquartered in Seattle, Washington, founded by Jerry Baldwin, Zev Siegl, and Gordon Bowker in 1971. Now, Starbucks as the world's largest coffeehouse chain is seen to be the main representation of the United States' second wave of coffee culture. This company become world-famous for high-quality coffee and beverages to its consumers over the world. The unique selling proposition concept will help Starbucks to face competition by differentiating their products and services and gain a competitive advantage over the competition, Starbucks is known for their good consumer service and in-store experience. And, the execution of corporate social responsibility is one of Starbucks' main marketing strategies in the improvement of coffee and tea farmer's lives as their priority together with saving the environment through more ecofriendly stores, reducing water consumption or serving coffee in recyclable cups (Namkung \& Jang, 2017).

Companies that consistently carry out their commitment to the environment is fair trade, organic, and eco-friendly labels have been particularly successful at conveying a positive image to consumers (Okumus et al., 2019). Starbucks has successfully applied their eco-friendly practice by publicly accessible and transparently show the process of making Starbucks products to the consumer. The two main objectives of eco-friendly are to improve the quality of the environment and to improve consumer satisfaction. 
According to (El-Kassar \& Singh, 2019), the increasing of consciousness in sustainable manufacturing and rising attention to the definition of eco-friendly assignment rules have led to a preliminary set of contributions and best, there is a large and diverse literature on the implementation of green initiative among business operators which indicates green initiatives are often initialized by changing business strategies that drive the innovation and product design as well the revamp of production processes. Then, a high degree of congruence between consumers and a company generated by environmental concerns tends to create a positive evaluation of a company's green initiatives, which, in turn, leads to a willingness to pay premiums for those initiatives (Kim et al., 2016).

More deeply, according to (Xu \& Jeong, 2019) in some cases, consumers may decide not to formally evaluate each brand, but in other cases, the factors that intervene can influence the final decision. So, decision making is an action taken to overcome the problems that occur and must be faced or the steps that are taken to achieve the goal as quickly as possible with the most efficient cost possible.

The author's reason for choosing Starbucks as the object of this research is because of their commitment to the environment, even though Starbucks is the biggest coffee company, they still have a concern for the environment and the most important thing is that they do not only do eco-friendly practice independently but also involve their consumers by building awareness of environmental and taking part in protecting the environment. Starbucks also apply a green initiative, it can be applied as a business strategy in long term, because it is generating profits while protecting the environment. It can make Starbucks have a strong green brand image in the consumer's mind to encourage consumers in making purchase decisions for Starbucks products.

This research will analyze the influence of eco-friendly practices, green brand image, and green marketing of Starbucks influence the number of tourists in Pontianak.

The concept of eco-friendly practices emerged as a concern for environmental damage issues which is used by companies as a competitive advantage. Then, apply green initiatives in the form of a program at several events can establish awareness of environmental sustainability to consumers, so that consumers will realize the benefits of green brand products, have the awareness of the environment, and it will create a green brand image of Starbucks in consumer's mind. If Starbucks product has a positive self-image in the eyes of consumers and it is believed to be able to meet the needs and desires of consumers, so consumers will be easily making a 
purchase decisions (Pandey et al., 2018). This research seeks to see how Eco-friendly Practices, Green Brand Image and Green Initiatives influence the number of tourists in Pontianak.

\section{Review Related Literature}

The practices of environmentally friendly have been long considered as an important component of company reputation and image. The consumers" perception of the image of environmentally friendly can be measured from the function of the practices of environmentally friendly which are important for the evaluation of greenness company (maharaja, 2018). In this case, companies that have a commitment to the environment and implement environmentally friendly practices will have a good reputation and have added value in the minds of consumers in making purchase decisions.

Green brand image is a set of perceptions that a consumer has on a brand-related to environmental sustainability (El-Kassar \& Singh, 2019). Similarly, green brand image is more important for companies especially under the rise of the prevalent environmental consciousness of consumers and strict international regulations of environmental protection. The green brand image also affects the company's reputation significantly, where a positive image is the first step towards success in attracting consumers in making a purchase decision and creating loyal consumers (Rehman Khan \& Yu, 2020).

Green Initiatives is a set of actions undertaken by a company to minimize the negative environmental effects associated with the entire life cycle of its products or services (Ch'ng et al., 2021). A company's identity is revealed by green initiatives, it can be relatively differentiated from others and able to enhance consumers" self-esteem. According to (Tih \& Zainol, 2012), consumers who have higher degrees of concern about environmental issues are more likely to identify with a company that exerts intensive green initiatives.

\section{Conceptual Framework}

The type of conceptual framework used in the research is multiple regression analysis, an analysis that measures the effect of independent variables on the dependent variable. The measurement of the influence in this research involved three independent variables $(X)$ and one dependent variable $(Y)$. In this research, the framework describes the relationship of the independent variables, Eco-friendly Practices (X1), Green Brand Image (X2), and Green 
Initiatives (X3) toward the dependent variable, number of tourists $(Y)$ in Pontianak. Research Hypotheses

Hypo means less than, while thesis means opinion. The hypothesis is an answer, opinion and temporary conclusion to the formulation of research problems, in which the formulation of the research problem has been stated in the form of a question sentence and has not yet been a thesis. It is said temporarily because the answers, opinions and conclusions given are only based on relevant theories, not based on empirical facts obtained through data collection. Based on the conceptual framework, the hypothesis is formulated as follows:

H1: Eco-friendly Practice (X1) influence Number of Visitor (Y)

H2: Green Brand Image (X2) influence Number of Visitor (Y)

H3: Green Initiatives (X3) influence Number of Visitor (Y)

\section{Research Methodology}

Data analysis is the activity of grouping and tabulating data based on variables from respondents, then presenting data from each variable studied, and performing calculations to test hypotheses (Sugiyono, 2014). In this research, the data will be analyzed by using the PASW Statistics 18 software application. PASW Statistics 18 is a comprehensive system for analyzing data, it can take data from almost any type of file and use them to generate tabulated reports, charts, and plots of distributions and trends, descriptive statistics, and complex statistical analyses (SPSS Inc., 2007).

\subsection{Test Research Instruments}

This research was conducted using a questionnaire tool, with data collection presented in the form of questions to the respondent associated with the services received, so that respondents can answer the questions by choosing the answer options that have been provided by the researcher according to the experience they can get from Starbucks. Respondent's answers will be measured by the Likert scale model according to is a variation of the summated rating scale, this scale asks a rater to agree or disagree with statements that express either favourable or unfavourable attitudes toward the object. The strength of attitude is reflected in the assigned score, and individual scores may be totalled for an overall 
Edutourism Journal of Tourism Research I p-ISSN: 2686-4746 | e-ISSN: 2721-1371

attitude measure. For each answer option given a score, the respondent must describe, support the statement, use the selected answer.

\subsection{Validity Test}

Validity is the level of reliability and validity of the measuring instrument used. In another sense, validity is the accuracy of interpretations made from the results of measurements or evaluations. The instrument is said to be valid, meaning that the measuring instrument used to obtain the data is valid or can be used to measure what should be measured (Sugiyono, 2014).

\subsection{Reliability Test}

A reliability test is defined as the consistency and stability of data or findings. From a positivistic perspective, reliability typically is considered to be synonymous with the consistency of data produced by observations made by different researchers, by the same researcher at different times, or by splitting a data set into two parts. Reliability relates to the consistency of an indicator (Dr Wahidmurni, 2017). Consistency indicates how well the items measuring a concept hang together as a set. Reliability shows the consistency of the measurements taken which include stability, equivalence, and internal consistency (Sugiyono, 2014).

\subsection{Linearity Test}

The linearity test aims to determine whether two variables have a linear or not significant relationship. Linearity is an assumption of correlation analysis, that the collection of data can be described by a straight line passing through the data array. Linearity is the nature of a linear relationship between variables, it means any changes that occur in one variable will be followed by a change with a magnitude that is parallel to the other variables. Test on SPSS using the Test for Linearity with a significance level of 0,05 . Two variables can be said to have a linear relationship if significance Linearity is less than 0,05 , which means that the linearity of the variable experience.

\subsection{Multiple Regression Analysis Test}

Multiple regression analysis used to predict how the condition (rise and fall) of the dependent variable (criterion) and if there are two or more independent variables as predictor factors that are manipulated (increase and decrease in value). Multiple linear regression 
analysis is used in this research to prove the hypothesis regarding the influence of the variable. Multiple regression is a statistical tool used to develop a self-weighing estimating equation that predicts values for a dependent variable from the values of independent variables, controls confounding variables to better evaluate the contribution of other variables, tests and explains a causal theory.

\subsection{Hypothesis Test}

The hypothesis that will be tested in this research is related to the existence of the significant effect of the independent variables (eco-friendly practice, green brand image and green initiatives) toward the dependent variable (purchase decision) either partially or simultaneously. In this research that will be examined is Eco-friendly Practice, Green Brand Image and Green Initiatives toward Purchase Decision.

\subsection{Determination Coefficient Test $\left(\mathbf{R}^{2}\right)$}

The determination coefficient test $\left(R^{2}\right)$ is to measure how far the model's ability in explaining the variance of the independent variable. Coefficient determination is between zero and one. A small $\mathrm{R}^{2}$ value means that the independent variables that can explain the dependent variable are very limited. A value close to one means that the independent variables provide almost all the information needed to predict the variation in the dependent variable. Coefficient determination is used to determine how much the influence of independent variables on the dependent variable. The coefficient determination value is determined by the $\mathrm{R}^{2}$ value.

Coefficient determination is part of the total diversity from the dependent variables that can be taken into account by the diversity of the independent variables, it is counted by coefficient determination with the basic assumption that other factors outside the variable are considered constant. 


\section{Results and Discussion}

Table 1. Respondents' Responses to Eco-Friendly Practices

\begin{tabular}{|c|c|c|c|c|c|c|}
\hline \multirow[t]{3}{*}{ Statement Item } & \multicolumn{5}{|c|}{ Alternative Answer } & \multirow{3}{*}{$\begin{array}{l}\text { Total } \\
\text { Score }\end{array}$} \\
\hline & SD & D & $\mathbf{N}$ & A & SA & \\
\hline & 1 & 2 & 3 & 4 & 5 & \\
\hline \multirow[t]{2}{*}{ Item 1} & 0 & 2 & 20 & 30 & 48 & 100 \\
\hline & 0 & 4 & 60 & 120 & 240 & 424 \\
\hline \multirow[t]{2}{*}{ Item 2} & 1 & 13 & 20 & 34 & 32 & 100 \\
\hline & 1 & 26 & 60 & 136 & 160 & 383 \\
\hline \multirow[t]{2}{*}{ Item 3} & 0 & 1 & 18 & 37 & 44 & 100 \\
\hline & 0 & 2 & 54 & 148 & 220 & 424 \\
\hline \multirow[t]{2}{*}{ Item 4} & 2 & 10 & 22 & 33 & 33 & 100 \\
\hline & 2 & 20 & 66 & 132 & 165 & 385 \\
\hline \multicolumn{7}{|c|}{ Variable Value Score of Eco-friendly Practices } \\
\hline \multicolumn{7}{|c|}{$\begin{array}{l}\text { Variable Average Score of Eco-friendly } \\
\text { Practices }\end{array}$} \\
\hline
\end{tabular}

Overall, it can be concluded that respondents of Starbucks Pontianak who is domiciled in Pontianak give positive responses to all items of the Eco-friendly Practices variable with an average value of 4,04 which is in the high category and for the standard deviation have an average of 1,039, which is means that the responses of respondents to the Eco-friendly variable are quite diverse.

Table 2. Respondents' Responses to Green Initiatives Practices

\begin{tabular}{|c|c|c|c|c|c|}
\hline \multirow{3}{*}{ Statement Item } & \multicolumn{3}{|c|}{ Alternative Answer } & \multirow[b]{2}{*}{ A } & \multirow[b]{2}{*}{ SA } \\
\hline & SD & $\mathrm{D}$ & $\mathbf{N}$ & & \\
\hline & 1 & 2 & 3 & 4 & 5 \\
\hline \multirow[t]{2}{*}{ Item 1} & 2 & 11 & 34 & 32 & 21 \\
\hline & 2 & 22 & 102 & 128 & 105 \\
\hline \multirow[t]{2}{*}{ Item 2} & 3 & 12 & 29 & 36 & 20 \\
\hline & 3 & 24 & 87 & 144 & 100 \\
\hline \multirow[t]{2}{*}{ Item 3} & 2 & 9 & 34 & 30 & 25 \\
\hline & 2 & 18 & 102 & 120 & 125 \\
\hline \multirow[t]{2}{*}{ Item 4} & 0 & 0 & 21 & 44 & 35 \\
\hline & 0 & 0 & 63 & 176 & 175 \\
\hline
\end{tabular}


Based on the data from table 4.11, it can be explained that the value of Asymp. Sig. (2-tailed) is 0,972 greater than 0,05 , so it can be concluded that the residuals of the data are normally distributed.

Table 3. One-Sample Kolmogorov-Smirnov Test

\begin{tabular}{|c|c|c|}
\hline & & $\begin{array}{r}\text { Unstandardized } \\
\text { Residual }\end{array}$ \\
\hline $\mathrm{N}$ & & 100 \\
\hline \multirow{4}{*}{$\begin{array}{r}\text { Normal } \\
\text { Parametersa,b }\end{array}$} & Mean & ,0000000 \\
\hline & & \\
\hline & Std. & 1,90207257 \\
\hline & Deviation & \\
\hline Most Extreme & Absolute & ,049 \\
\hline \multirow[t]{2}{*}{ Differences } & Positive & ,036 \\
\hline & Negative &,- 049 \\
\hline Kolmogorov- & & ,486 \\
\hline Smirnov Z & & \\
\hline $\begin{array}{r}\text { Asymp. Sig. (2- } \\
\text { tailed) }\end{array}$ & & ,972 \\
\hline
\end{tabular}

Based on the data from table 4.11, it can be explained that the value of Asymp. Sig. (2-tailed) is 0,972 greater than 0,05 , so it can be concluded that the residuals of the data are normally distributed.

Table 4. Respondents' Responses to Brand Image

\begin{tabular}{|c|l|c|c|c|}
\hline Hypotheses & \multicolumn{1}{|c|}{ Path } & Beta & Sig & \multicolumn{1}{c|}{ Explanation } \\
\hline H1 & $\begin{array}{l}\text { Eco-friendly Practices } \rightarrow \\
\text { Number of Tourist }\end{array}$ & 0,232 & 0,005 & H1 accepted \\
\hline H2 & $\begin{array}{l}\text { Green Brand Image } \rightarrow \\
\text { Number of Tourist }\end{array}$ & 0,437 & 0,000 & H2 accepted \\
\hline H3 & $\begin{array}{l}\text { Green Initiatives } \rightarrow \\
\text { Number of Tourist }\end{array}$ & 0,254 & 0,003 & H3 accepted \\
\hline
\end{tabular}


Based on table 4.19 , after testing the hypothesis it can be concluded that three hypotheses formulated by the researcher are accepted. Based on the results of data processing, a conceptual framework for the results of the research can be produced as follows:

\section{Discussion}

Eco-Friendly Practices have a significant effect on the Number of Tourists in Pontianak The influence of Eco-friendly Practices (X1) toward Purchase Decision (Y) is as shown in table 4.18 above, showing that $t$ count is 2,897 while $t$ table is 1,984 . It can be concluded that $t$ count 3,027 > 1,984 $\mathrm{t}$ table and the Significant value of Eco-friendly Practices (X1) is 0,003 > 0,05. So that the hypothesis is accepted, which means that there is a significant effect between Ecofriendly Practices (X1) toward the number of Tourist $(Y)$. The results of this study support the research conducted by (Lee et al., 2020) entitled "Pro-environmental Concern Influencing Green Buying: A Study on Indian Consumers". The results of this research indicate that Ecofriendly Practices variable simultaneously influences the number of tourists in Pontianak.

Grand Brand Image have a significant effect on the number of tourists in Pontianak. The influence of Green Brand Image (X2) toward Purchase Decision (Y) is as shown in table 4.18 above, showing that $t$ count is 5,518 while $t$ table is 1,984 . It can be concluded that $t$ count 5,518 $>1,984 \mathrm{t}$ table and the Significant value of Green Brand Image $(\mathrm{X} 2)$ is $0,000>0,05$. So that the hypothesis is accepted, which means that there is a significant effect between Green Brand Image (X2) toward several tourists (Y).

The results of this study support the research conducted by (Langgat, 2020) entitled "The Effect of Green Marketing on Brand Image and Purchase Decision (Study on the restaurant)". The results of this research indicate that the Green Brand Image variable simultaneously influences several tourists.

The influence of Green Initiatives (X3) toward Purchase Decision $(\mathrm{Y})$ is as shown in table 4.18 above, showing that the $t$ count is 3,027 while the $t$ table is 1,984 . It can be concluded that $\mathrm{t}$ count 3,027 >1,984 $\mathrm{t}$ table and the Significant value of Green Brand Image (X3) is 0,003 >0,05. 
So that the hypothesis is accepted, which means that there is a significant effect between Green Initiatives $(\mathrm{X} 3)$ toward several tourists $(\mathrm{Y})$.

The results of this study support the research conducted by (Rehman Khan \& Yu, 2020) entitled "Consumers"e willingness to pay for green initiatives of the hotel industry". The results of this research indicate that the Green Initiatives variable simultaneously influences Purchase Decision.

\section{Conclusion}

Based on the test results of the partial test (T-test) carried out toward Eco- friendly Practices obtained from the comparison of the sig value and the significance level, so it can be concluded that Ha is accepted and Ho is rejected, which is means that the regression coefficient on the Eco-friendly Practices partially affects the number of tourist in Pontianak.

Based on the test results of the partial test (T-test) carried out toward Green Brand Image obtained from the comparison of the sig value and the significance level, so it can be concluded that Ha is accepted and Ho is rejected, which is means that the regression coefficient on the Green Brand Image partially affects some tourists.

Based on the test results of the partial test (T-test) carried out toward Green Initiatives obtained from the comparison of the sig value and the significance level, so it can be concluded that Ha is accepted and Ho is rejected, which is means that the regression coefficient on the Green Initiatives partially affects the purchase decision.

Based on the test results simultaneously (F Test), it can be concluded that the variable of Ecofriendly Practices, Green Brand Image, Green Initiatives simultaneously have a significant effect on the number of tourists in Pontianak. 


\section{Author's declaration}

\section{Authors' contributions and responsibilities}

$\sqrt{ }$ The authors made substantial contributions to the conception and design of the study.

$\sqrt{ }$ The authors took responsibility for data analysis, interpretation and discussion of results.

$\sqrt{ }$ The authors read and approved the final manuscript.

\section{Availability of data and materials}

$\sqrt{ }$ All data are available from the authors.

\section{Competing interests}

$\sqrt{ }$ The authors declare no competing interest. 


\section{Referensi}

[1] Ch'ng, P.-C., Cheah, J., \& Amran, A. (2021). Eco-innovation practices and sustainable business performance: The moderating effect of market turbulence in the Malaysian technology industry. Journal of Cleaner Production, 283, 124556.

[2] Dr. Wahidmurni, M. P. (2017). Pemaparan Metode Penelitian Kualitatif. UIN Maulana Malik Ibrahim.

[3] El-Kassar, A.-N., \& Singh, S. K. (2019). Green innovation and organizational performance: the influence of big data and the moderating role of management commitment and HR practices. Technological Forecasting and Social Change, 144, 483498.

[4] Jermsittiparsert, K., Siriattakul, P., \& Wattanapongphasuk, S. (2019). Determining the environmental performance of Indonesian SMEs influence by green supply chain practices with moderating role of green HR practices. International Journal of Supply Chain Management, 8(3), 59-70.

[5] Kim, J.-Y., Hlee, S., \& Joun, Y. (2016). Green practices of the hotel industry: Analysis through the windows of the smart tourism system. International Journal of Information Management, 36(6), 1340-1349.

[6] Langgat, J. (2020). Route to Green Restaurant: Malaysian Perceptions and Attitudes. International Journal of Business and Social Science, 11(5).

[7] Lee, M. J., Kang, H., Choi, H., \& Olds, D. (2020). Managerial attitudes towards green practices in educational restaurant operations: An importance-performance analysis. Journal of Hospitality \& Tourism Education, 32(3), 142-155.

[8] Namkung, Y., \& Jang, S. (2017). Are consumers willing to pay more for green practices at restaurants? Journal of Hospitality \& Tourism Research, 41(3), 329-356.

[9] Okumus, F., Köseoglu, M. A., Chan, E., Hon, A., \& Avci, U. (2019). How do hotel employees' environmental attitudes and intentions to implement green practices relate to their ecological behaviour? Journal of Hospitality and Tourism Management, 39, 193-200. 
[10] Pandey, R. U., Surjan, A., \& Kapshe, M. (2018). Exploring linkages between sustainable consumption and prevailing green practices in reuse and recycling of household waste: Case of Bhopal city in India. Journal of Cleaner Production, 173, 49-59.

[11] Rehman Khan, S. A., \& Yu, Z. (2020). Assessing the eco-environmental performance: a PLS-SEM approach with a practice-based view. International Journal of Logistics Research and Applications, 1-19.

[12] Sugiyono. (2014). Metode Penelitian Kuantitati Kualitatif Dan RED. CV. Alfabeta.

[13] Tih, S., \& Zainol, Z. (2012). Minimizing waste and encouraging green practices. Jurnal Ekonomi Malaysia, 46(1), 157-164.

[14] Xu, Y., \& Jeong, E. (2019). The effect of message framings and green practices on customers' attitudes and behavioural intentions toward green restaurants. International Journal of Contemporary Hospitality Management. 